DOI 10.15290/cnisk.2018.01.04.05

DR HAB. KRYSTYNA LEŚNIAK-MOCZUK, PROF. UR

orcid.org/0000-0001-7032-9205

Uniwersytet Rzeszowski

\title{
Aktywność kobiet na tle mężczyzn w sferze zawodowej w Polsce wschodniej
}

\section{Streszczenie}

W artykule dokonano oceny usytuowania kobiet w sferze zawodowej w odniesieniu do mężczyzn na podstawie następujących wskaźników: wykształcenie, aktywność zawodowa, zatrudnienie, bezrobocie, pracujacy według sektorów ekonomicznych, wynagrodzenie, zwolnienia z pracy i przyjęcia do pracy, migracje zagraniczne oraz czynniki przedsiębiorczości. Przedmiotem analizy są wskaźniki $z$ lat 2014-2015 z pięciu wschodnich województw (lubelskie, podkarpackie, podlaskie, świętokrzyskie, warmińsko-mazurskie) na tle Polski.

Słowa kluczowe: kobiety, mężczyźni, sfera zawodowa, wschodnie województwa

\section{WOMEN'S AND MEN'S PROFESSIONAL ACTIVITY IN EASTERN POLAND}

\begin{abstract}
The purpose of the following article is to provide a summary and evaluation of women's roles in the professional space as compared to men's, taking into consideration such indicators as: education, occupational activity, employment and unemployment according to economic sectors, wages, dismissals from work, foreign migrations and entrepreneurial factors.
\end{abstract}


The following analysis focuses on data collected between 2014 and 2015 in five Eastern voivodships: Lubelskie, Podkarpackie, Podlaskie, Świętokrzyskie, Warmia and Mazury against the rest of the country.

Keywords: women, men, occupational sphere, Eastern voivodships

\section{Wstęp}

U progu ery nowożytnej oddzielenie sfery zawodowej od gospodarstwa domowego spowodowało wzrost zaangażowania mężczyzn poza domem, co wpłynęło na zwiększenie obciążenia kobiet obowiąkami rodzinnymi ${ }^{1}$. Wraz z postępem cywilizacyjnym kobiety wciagnięte $\mathrm{w}$ wir życia zawodowego uczyły się godzić zwielokrotnione obowiazki. Wzrastajacy popyt na siłę roboczą kobiet nie szedł w parze $z$ odpowiednimi regulacjami rynku pracy. Dopiero zmiany ustawodawstwa zabezpieczającego prawa społeczne i wzmożenie ruchów feministycznych prowadziły do stopniowej poprawy położenia kobiet. Pomimo działań polityki społecznej na rzecz zabezpieczenia praw kobiet ciagle dostrzega się nowe miejsca występowania nierówności społecznych ze skutkami negatywnymi dla kobiet. Zabezpieczenie ich praw nie przekłada się na realne wskaźniki satysfakcjonujące kobiety, które uwikłane sa w pochłaniające je role społeczne we wszystkich sferach życia rodzinnego, zawodowego i publicznego.

Aktywność zawodowa kobiet ma nie tylko materialny wymiar wyrażany finansowym wkładem do gospodarstwa domowego czy wymiar społeczny wyznaczany prestiżem i awansem zawodowym, lecz także wartość symboliczną wpływającą na zmianę stosunków władzy w małżeństwie, uwolnienie od pośredniego statusu płatnej pomocy, rozluźnienie powiązań $z$ rodziną i usamodzielnienie w relacji do małżeństwa. Pojawienie się nowych obciążeń kobiet związanych $z$ pracą zawodową nie ujmuje jej domowych obowiązków, ale uwalnia kobietę od całkowitego „roztopienia się" w pracy w gospodarstwie domowym i unieruchomienia $z$ powodu małżeństwa. $Z$ drugiej strony dostrzeganie własnych interesów, zrównanie dostępu do studiów, wykształcenie i mobilność wzmagajace proces indywidualizacji kobiety w zwiąkkach rodzinnych są równocześnie zagrożeniem dla wypełniania funkcji rodzinnych. W społeczeństwie ponowoczesnym rekonstrukcji wymagają stosunki między kobietami

\footnotetext{
1 Z. Bauman, R. Kubicki, A. Zeidler-Janiszewska, Życie w kontekstach. Rozmowy o tym, co za nami i o tym, co przed nami, Warszawa 2009, s. 258.
} 
i mężczyznami wynikające $z$ ról biologicznych płci żeńskiej - małżeństwo, rodzicielstwo, czułość, seksualność uzupełniane o role społeczne wynikające $z$ płci kulturowej - wykształcenie, praca, zawód, mobilność, prawo, polityka, pieniądze, ekonomia ${ }^{2}$. Zakres zaangażowania w poszczególne obszary życia powinien być dobrowolnym wyborem indywidualnym kobiety, umożliwionym poprzez warunki ekonomiczne rodziny, skuteczną politykę społeczną wobec rodziny oraz opinię publiczną przyzwalająca na życiowe preferencje. Tak więc każda kobieta powinna mieć możliwość wyboru realizacji swojej drogi życiowej spośród zaproponowanych alternatywnych scenariuszy, uwzględniajacych obszary aktywności kobiet: łączenie aktywności w sferze rodzinnej, zawodowej i publicznej przy korzystaniu $z$ instytucji uzupełniających funkcje rodziny, zróżnicowanie nasilenia kombinacji sfer aktywności w poszczególnych etapach życia, realizacja indywidualnej kariery w sferze zawodowej i publicznej, spełnianie się w życiu rodzinnym.

Celem niniejszego artykułu jest próba oceny relacji między kobietami i mężczyznami w wybranych obszarach sfery zawodowej w pięciu wschodnich województwach na tle Polski. W artykule skupiono uwage na czynnikach przedsiębiorczości kobiet, wybranych aspektach sytuacji kobiet i mężczyzn w sferze zawodowej w pięciu województwach Polski wschodniej (lubelskie, podkarpackie, podlaskie, świętokrzyskie, warmińsko-mazurskie) na tle ogólnopolskim. Wybór obszaru badawczego zdeterminowany był programem IV Wschodniego Kongresu Gospodarczego, największej debaty o perspektywach Polski wschodniej, odbywającego się w dniach 27-28 września 2017 r. w Białymstoku, na trwałe wpisanego w kalendarz najważniejszych gospodarczych konferencji w Polsce. Coroczna wielostronna debata polityków i samorządowców, ludzi nauki i gospodarki zogniskowana jest na stałych obszarach tematycznych dotyczących przedsiębiorczości i otoczenia biznesu, wspólpracy gospodarczej oraz relacji z Europa i wschodnimi sąsiadami Polski. Do atutów i barier rozwojowych stanowiących o specyfice Polski wschodniej wpisano aktualne wątki i szczegółowe kwestie definiujące szanse i wyzwania kluczowe dla budowania strategii rozwoju regionu. Po raz pierwszy na Kongresie wśród tych aktualnych zagadnień społeczno-gospodarczych znalazła się tematyka kobiet $\mathrm{w}$ gospodarce makroregionu.

2 U. Beck, Społeczeństwo ryzyka. W drodze do innej nowoczesności, przeł. S. Cieśla, Warszawa 2002, s. 120-122, 151. 
Do ilustracji usytuowania kobiet w sferze zawodowej w odniesieniu do mężczyzn wybrano niżej analizowane wskaźniki: wykształcenie, aktywność zawodowa, zatrudnienie, bezrobocie, pracujacy według sektorów ekonomicznych, zwolnienia $z$ pracy i przyjęcia do pracy, migracje zagraniczne oraz wynagrodzenie. Przedmiotem tej analizy uczyniono parametry określające poziom wybranych wskaźników położenia kobiet i mężczyzn w sferze zawodowej w roku 2015 (wykształcenie, płace, fluktuacja) i 2016 (aktywność zawodowa, zatrudnienie, bezrobocie, migracje).

Artykuł stanowi przyczynek do dalszych badań ukierunkowanych na kształtowanie się relacji pomiędzy płciami w pełnieniu przez nie ról społecznych w sferze rodzinnej, zawodowej i publicznej.

\section{Czynniki przedsiębiorczości kobiet}

Z badań jakościowych Barbary Marek-Zborowskiej dotyczacych czynników i barier w dążeniu do karier kobiet sukcesu, przeprowadzonych w województwie podkarpackim, wynika, że przedsiębiorczość polskich kobiet jest większa niż w krajach Unii Europejskiej. Uwarunkowaniami tej przedsiębiorczości są: motywacje do pracy na własny rachunek zdeterminowane brakiem alternatywy, dążenie do niezależności, konieczność uzyskiwania dochodów, chęć rozwoju zawodowego, negatywne cechy pracy najemnej oraz warunki rynkowe. Kobiety przedsiębiorcze, decydując się na samodzielność w prowadzeniu biznesu, nie kierują się chęcia ryzyka, wykorzystaniem szansy czy realizacją marzeń. Jedynymi zaś barierami sa dla nich brak kapitału i strach przed ryzykiem, a także brak solidarności kobiet.

Na rynku pracy i w biznesie doceniane sa cechy i umiejętności kobiet oraz ich intuicyjno-wspólnotowe racjonalności, odmienne od męskich logiczno-instrumentalnych. Kobiety koncentrują się na środowisku pracy, własnym rozwoju, a mężczyźni na prestiżu, władzy, wynagrodzeniach, szybkim zysku. Dla większości kobiet kierownicze stanowiska nie sa atrakcyjne i dlatego są w mniejszym stopniu skłonne do poświęceń, by osiagnać władzę, prestiż, wysokie zarobki. Postulat równych szans to równy dostęp do awansu i hierarchii organizacji. Kobiety wnoszą do organizacji „miękki styl”: witalność, empatię, intuicję, atmosferę, współpracę, komunikatywność, zaangażowanie w doprowadzeniu spraw do końca, demokratyczne przywództwo, łagodzenie hierarchizacji oraz orientację na zaspokojenie potrzeb, uczestnictwo i komunikację. W zarządzaniu 
preferuja interes większości pracowników, a w zawodzie pracę zgodna $z$ wartościami, samodzielność decyzji, atmosferę, relacje $z$ pracownikami, podwładnymi i szefem.

Czynnikami sukcesu kobiet są: wiedza, wykształcenie, zdolności, ambicja, charakter, cechy psychiczne, otwarcie na klienta, kompetencja, zaangażowanie, rzetelność, ciężka praca, styl zarządzania, satysfakcjonujący trwały zwiazek, wspólne gospodarstwo i zainteresowania, wysoka pozycja zawodowa męża, zabezpieczenie finansowe. Zdaniem kobiet parytety jako bonusy za płeć sa niedopuszczalne. To poszkodowana mniejszość nieuczciwie domaga się równego traktowania, a w biznesie nie pomoga dodatkowe regulacje prawne i sztuczne parytety. Zdobywanie wiedzy i umiejętności zawodowych zależy przede wszystkim od rodziny. Przy wyborze drogi życiowej dzięki rodzinie kobiety zyskują kumulacje wiedzy o funkcjonowaniu rzeczywistości, wskazówki o opłacalności inwestowania w zawody, a wzorce i rady rodziców ułatwiaja projekcję własnych aspiracji. Spośród cech przekazanych przez rodziców największe znaczenie mają: przeciętne i wyższe dochody rodziny, uczciwość, rzetelny stosunek do pracy, samodzielne myślenie, pomaganie innym i zaradność. W hierarchii wartości kobiet poczesne miejsce zajmuja rodzina, praca zawodowa, ideały, a najniższe władza, polityka i życie publiczne oraz wysokie dochody. Wpływają one na wyznaczanie następujących celów życiowych: sfera zawodowa, sfera rodzinna, wiedza i kwalifikacje, prestiż społeczny i władza ${ }^{3}$.

\section{Poziom wykształcenia}

Poziom wykształcenia w znacznym stopniu powinien determinować sytuację zawodowa na rynku pracy. Prawidłowość ta nie zawsze sprawdza się w praktyce. Struktura wykształcenia według kryterium płci nie idzie w parze $z$ losami zawodowymi kobiet i mężczyzn. Kobiety w porównaniu do mężczyzn są lepiej wykształcone, co nie gwarantuje im lepszego startu w życie zawodowe i awansów na kolejne szczeble kariery zawodowej. Wykresy nr 1 i nr 2 ilustruja poziom wykształcenia kobiet i mężczyzn w badanych jednostkach terytorialnych.

3 B. Marek-Zborowska, Kobiety sukcesu $i$ ich kariery $w$ województwie podkarpackim, Rzeszów 2016, s. 121-122, 128-129, 133, 136, 195-196, 259, 265-266, 272-273, 276 277, 293, 297, 301, 309-310. 
Wykres 1. Wykształcenie kobiet w Polsce i w pięciu województwach w $2015 \mathrm{r}$.

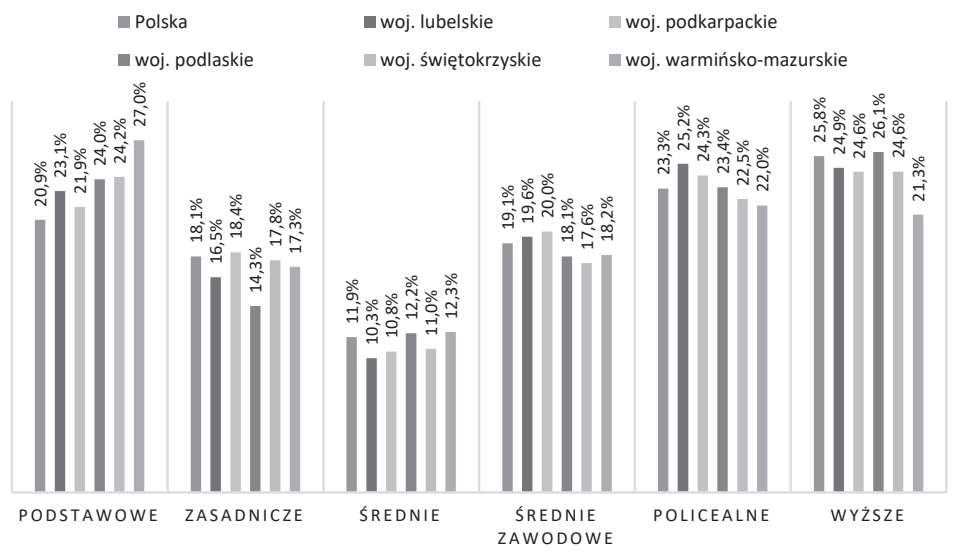

Źródło: opracowanie własne na podstawie danych z Urzędu Statystycznego $w$ Rzeszowie.

Wykres 2. Wykształcenie mężczyzn w Polsce i w pięciu województwach w $2015 \mathrm{r}$.

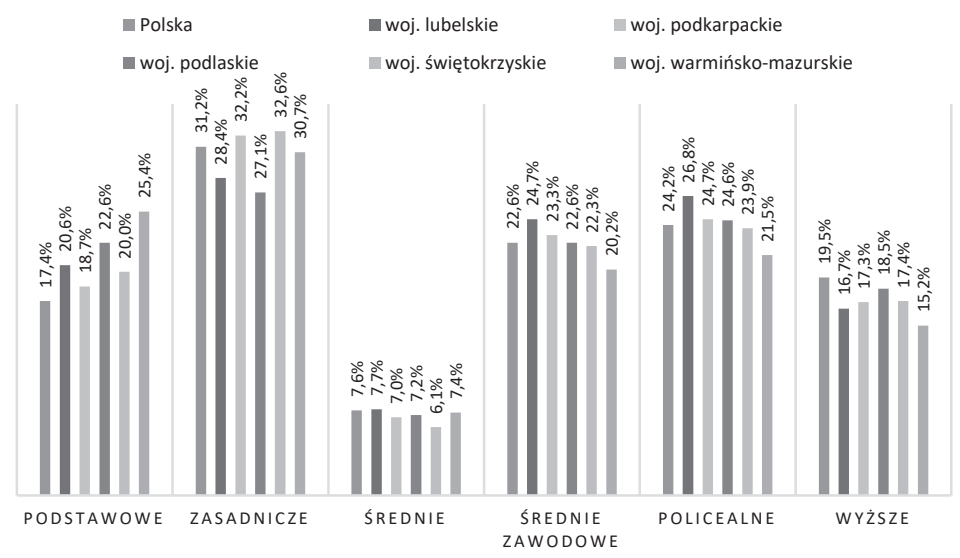

Źródło: opracowanie własne na podstawie danych z Urzędu Statystycznego $w$ Rzeszowie.

W skali kraju więcej kobiet niż mężczyzn ma wykształcenie wyższe (o 6,3 pkt. proc.) i średnie (o 4,3 pkt. proc.), a mniej zasadnicze (o 13,1 pkt. proc.), średnie zawodowe (o 3,5 pkt. proc.) i policealne 
(o 0,9 pkt. proc.). Więcej kobiet niż mężczyzn (o 3,5 pkt. proc.) ma wykształcenie podstawowe. Posiadanie tego rodzaju wykształcenia dotyczy pokolenia starszego, a przewaga kobiet wynika $z$ nadreprezentatywności pań w wieku poprodukcyjnym. $Z$ pięciu województw tylko woj. podlaskie ma lepszy wskaźnik wykształcenia wyższego kobiet niż średnia krajowa (o 0,3 pkt. proc.), a w woj. warmińsko-mazurskim wskaźnik ten ma wartość najniższa (o 4,5 pkt. proc. w stosunku do krajowego). Największa rozpiętość wykształcenia wyższego na korzyść kobiet jest w woj. lubelskim (8,2 pkt. proc.), najmniejsza zaś w woj. warmińsko-mazurskim (6,1 pkt. proc.). Najwięcej kobiet w stosunku do mężczyzn ma wykształcenie średnie w woj. podlaskim (o 5,0 pkt. proc.), a najmniej w woj. lubelskim $(2,6$ pkt. proc.). Największa przewaga mężczyzn $z$ wykształceniem zasadniczym jest w woj. świętokrzyskim (15,0 pkt. proc.), a najmniejsza w woj. lubelskim (11,9 pkt. proc.), $\mathrm{z}$ wykształceniem średnim zawodowym - największa w woj. lubelskim (5,1 pkt. proc.), a najmniejsza w woj. warmińsko-mazurskim (2,4 pkt. proc.), $\mathrm{z}$ wykształceniem policealnym - największa w woj. lubelskim (1,6 pkt. proc.), a najmniejsza w woj. podkarpackim (0,3 pkt. proc.).

Generalnie struktura wykształcenia kobiet i mężczyzn w badanych województwach Polski wschodniej jest mniej korzystna aniżeli struktura wykształcenia w skali ogólnopolskiej. Udział osób z wykształceniem podstawowym w pięciu badanych województwach jest wyższy w porównaniu do skali krajowej, a udział osób $z$ wykształceniem wyższym jest niższy. Wskaźniki pozostałych typów wykształcenia w tych województwach oscylują wokół średniej krajowej. Najlepiej pod względem struktury wykształcenia kobiet i mężczyzn plasuje się woj. lubelskie, a najmniej korzystniej woj. warmińsko-mazurskie.

\section{Aktywność zawodowa}

Do aktywnych zawodowo zalicza się osoby pracujace, poszukujace pracy, bezrobotne i niepełnosprawne. Płeć determinuje aktywność w sferze zawodowej. Na poziom aktywności zawodowej kobiet wpływa więcej czynników aniżeli w przypadku płci męskiej. Biologicznie uwarunkowane role społeczne kobiet i zwiazane $z$ tym obowiazki rodzinne oraz kultywowany, szczególnie w starszym pokoleniu, obyczajowy podział zadań dla kobiet i mężczyzn w gospodarstwie domowym sytuują kobiety 
$\mathrm{w}$ innej pozycji na rynku pracy w porównaniu $\mathrm{z}$ mężczyznami. Ten stan rzeczy w badanych województwach odzwierciedla wykres 3 .

Wykres 3. Wskaźnik aktywności zawodowej ludności w wieku 15 lat i więcej w Polsce oraz w pięciu województwach w 2016 r.

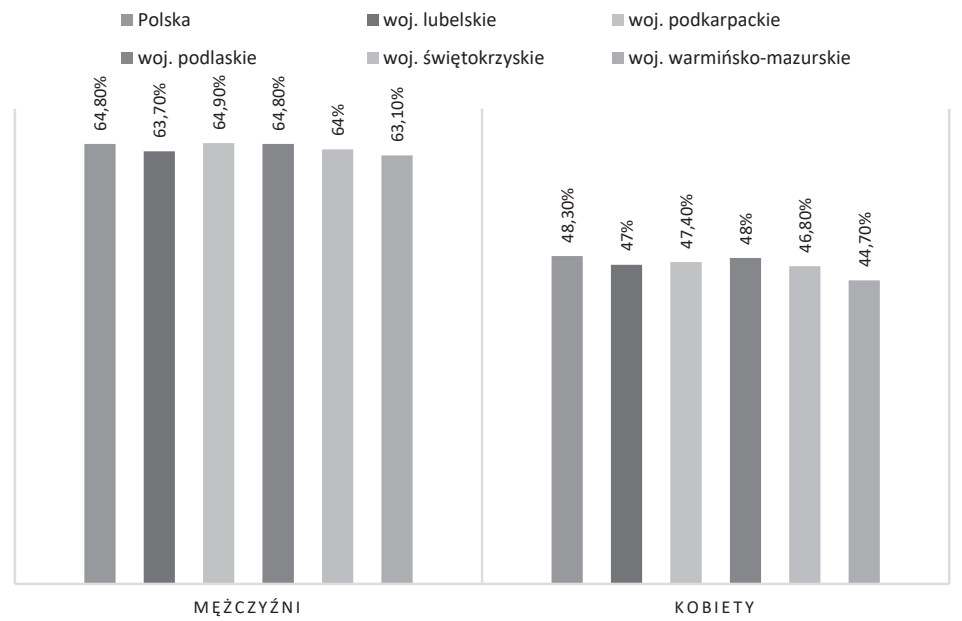

Źródło: opracowanie własne na podstawie danych z Urzędu Statystycznego $w$ Rzeszowie.

W skali kraju wskaźnik aktywności zawodowej kobiet jest o 16,5 pkt. proc. niższy w porównaniu do mężczyzn i wynosi $48,3 \%$. Wskaźnik ten w badanych województwach oscyluje wokół 44,7-48,3\%. Wskaźnik aktywności zawodowej mężczyzn jest o połowę mniej zróżnicowany terytorialnie. Jego wartości mieszczą się w granicach 63,1-64,9\%. W woj. lubelskim i podlaskim wskaźnik aktywności zawodowej kobiet jest niższy o 16,8 pkt. proc. w stosunku do wskaźnika aktywności zawodowej mężczyzn w tych województwach, w woj. podkarpackim i świętokrzyskim o 17,5 pkt. proc., a w woj. warmińsko-mazurskim różnica ta jest największa i wynosi 18,4 pkt. proc. $Z$ badanych pięciu województw tylko woj. podlaskie ma najbardziej zbliżony wskaźnik aktywności zawodowej kobiet do tego wskaźnika w skali kraju (niższy o 0,3 pkt. proc.), a w woj. warmińsko-mazurskim jest on najniższy (o 3,6 pkt. proc.). 


\section{Wskaźnik zatrudnienia}

Z poziomu aktywności zawodowej wynika stan zatrudnienia, który również uwarunkowany jest różnicami płci. Skalę tych uwarunkowań we wschodnich województwach oddaje poniższe zestawienie danych statystycznych.

Wykres 4. Wskaźnik zatrudnienia ludności w wieku 15 lat i więcej w Polsce i w pięciu województwach w 2016 r.

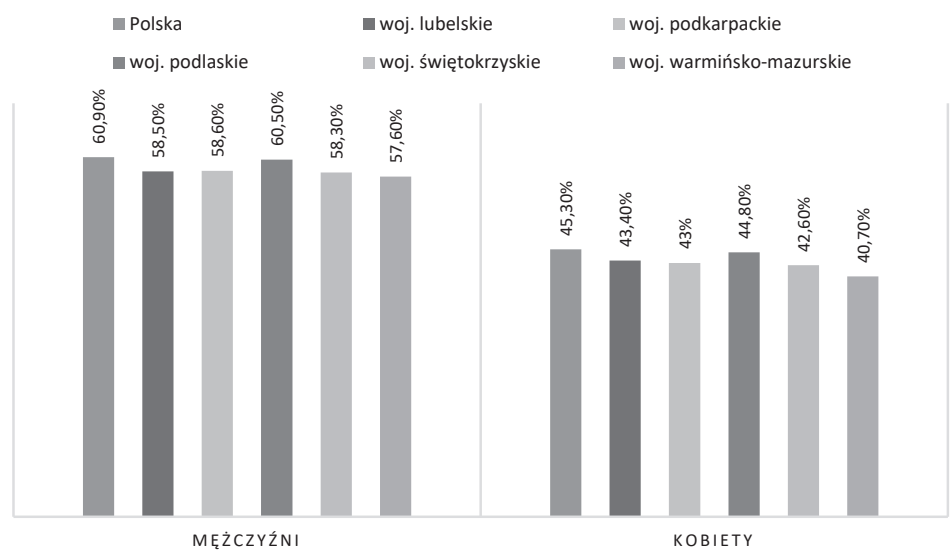

Źródło: opracowanie własne na podstawie danych z Urzędu Statystycznego $w$ Rzeszowie.

W skali kraju wskaźnik zatrudnienia kobiet jest o 15,6 pkt. proc. niższy w porównaniu do wskaźnika zatrudnienia mężczyzn i wynosi 45,3\%. We wszystkich pięciu województwach wskaźnik zatrudnienia kobiet osiaga wartości niższe niż ogólnokrajowy i wskaźniki zatrudnienia mężczyzn w tych województwach. W woj. podlaskim wskaźnik zatrudnienia kobiet jest tylko o 0,5 pkt. proc. niższy w porównaniu do średniej krajowej, a w woj. warmińsko-mazurskim jest on najniższy o 4,6 pkt. proc. W woj. lubelskim wskaźnik zatrudnienia kobiet jest niższy o 15,1 pkt. proc. w stosunku do wskaźnika zatrudnienia mężczyzn, a w woj. warmińsko-mazurskim jest niższy o 16,9 pkt. proc.

Wartości wskaźnika zatrudnienia zarówno kobiet, jak i mężczyzn w woj. podlaskim sa najbardziej zbliżone do wartości tego wskaźnika w skali krajowej (niższy o 0,4 pkt. proc. - mężczyźni, 0,5 - kobiety), a naj- 
niższy poziom wykazują w woj. warmińsko-mazurskim (niższy o 3,3 pkt. proc. - mężczyźni, o 4,6 - kobiety).

\section{Stopa bezrobocia}

Bezrobocie traktowane jako stan aktywności zawodowej osób, które sa zdolne i gotowe do podjęcia zatrudnienia, lecz nie są zatrudnione, nie prowadzą działalności gospodarczej i innej pracy zarobkowej, jest zjawiskiem generującym koszty w gospodarce oraz przynoszacym negatywne skutki w skali społecznej i indywidualnej bezrobotnych. Według powszechnej opinii potwierdzanej wynikami badań naukowych skala negatywnych skutków bezrobocia jest zdeterminowana płciowo. Wśród bezrobotnych kobiet obserwuje się mniejsze nasilenie patologii społecznych. Wynikać to może m.in. $z$ większego obciażenia kobiet obowiązkami w sferze rodzinnej. Poziom stopy bezrobocia jako relacji liczby bezrobotnych do aktywnych zawodowo jest zróżnicowany według kryterium płci. Poniższe zestawienia ilustruja skalę tego zjawiska w skali kraju i województwach wschodniej Polski w 2016 r.

Wykres 5. Stopa bezrobocia ludności w wieku 15 lat i więcej w Polsce i w pięciu województwach w 2016 r.

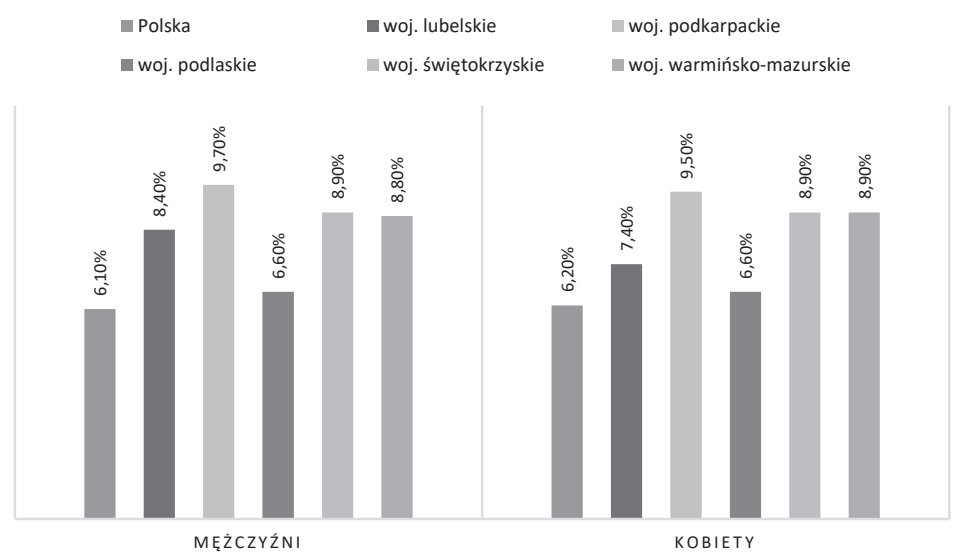

Źródło: opracowanie własne na podstawie danych z Urzędu Statystycznego $w$ Rzeszowie.

W skali kraju stopa bezrobocia kobiet jest porównywalna ze stopa bezrobocia mężczyzn (o 0,1\% wyższa). We wszystkich pięciu wojewódz- 
twach stopa bezrobocia kobiet i mężczyzn osiaga wartości wyższe niż ogólnokrajowe. W woj. podlaskim stopa bezrobocia kobiet osiaga najniższe wartości (o 0,4 pkt. proc. wyższa od średniej krajowej) i jest na takim samym poziomie jak stopa bezrobocia mężczyzn. W woj. podkarpackim jest największa (wyższa o 3,3 pkt. proc. od średniej krajowej). Stopa bezrobocia kobiet jest niższa od stopy bezrobocia mężczyzn w woj. lubelskim o 1 pkt. proc. i tylko w woj. warmińsko-mazurskim jest wyższa (o 0,1 pkt. proc.).

Stopa bezrobocia kobiet, podobnie jak i mężczyzn jest zróżnicowana terytorialnie. Na Podkarpaciu jest najwyższa w porównaniu do skali krajowej, a na Podlasiu najniższa. Poziom stopy bezrobocia nie jest w dużym stopniu zróżnicowany płciowo.

\section{Struktura zatrudnienia według sektorów}

Poziom postępu cywilizacyjnego w gospodarce wyznacza stan rozwoju jej sektorów ekonomicznych. Tendencje obserwowane w krajach rozwiniętych zmierzają do ekspansji sektora usług przy kurczeniu się sektora rolniczego. Wyznacznikiem rozwoju tych sektorów jest poziom zatrudnienia. Dywersyfikację zatrudnienia według płci w Polsce i pięciu województwach na jej ścianie wschodniej w 2016 r. ilustruja poniższe zestawienia statystyczne. 
Wykres 6. Pracujacy wg sektorów ekonomicznych w Polsce w 2016 r. (w \%)

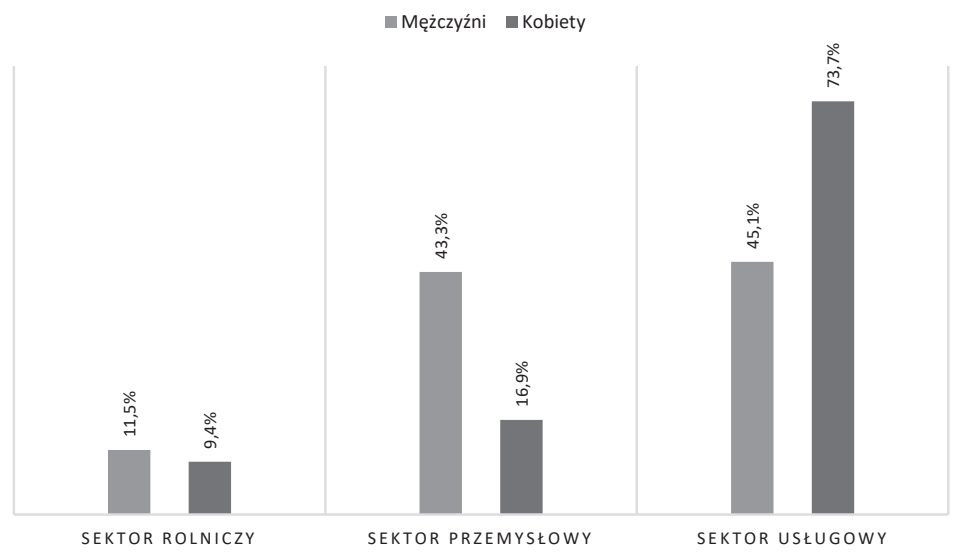

Źródło: opracowanie własne na podstawie danych z Urzędu Statystycznego $w$ Rzeszowie.

Struktura zatrudnienia w Polsce według sektorów ekonomicznych osiaga parametry cechujacce nowoczesne gospodarki. Kobiety w porównaniu $z$ mężczyznami dominują w zatrudnieniu w sektorze usług (wsk. wyższy o 28,6 pkt. proc.), w pozostałych zaś sektorach zatrudnionych jest więcej mężczyzn niż kobiet, w rolnictwie tylko o 2,1 pkt. proc., a w przemyśle aż o 26,6 pkt. proc. 
Wykres 7. Pracujące kobiety wg sektorów ekonomicznych w pięciu województwach w 2016 r. (w \%)

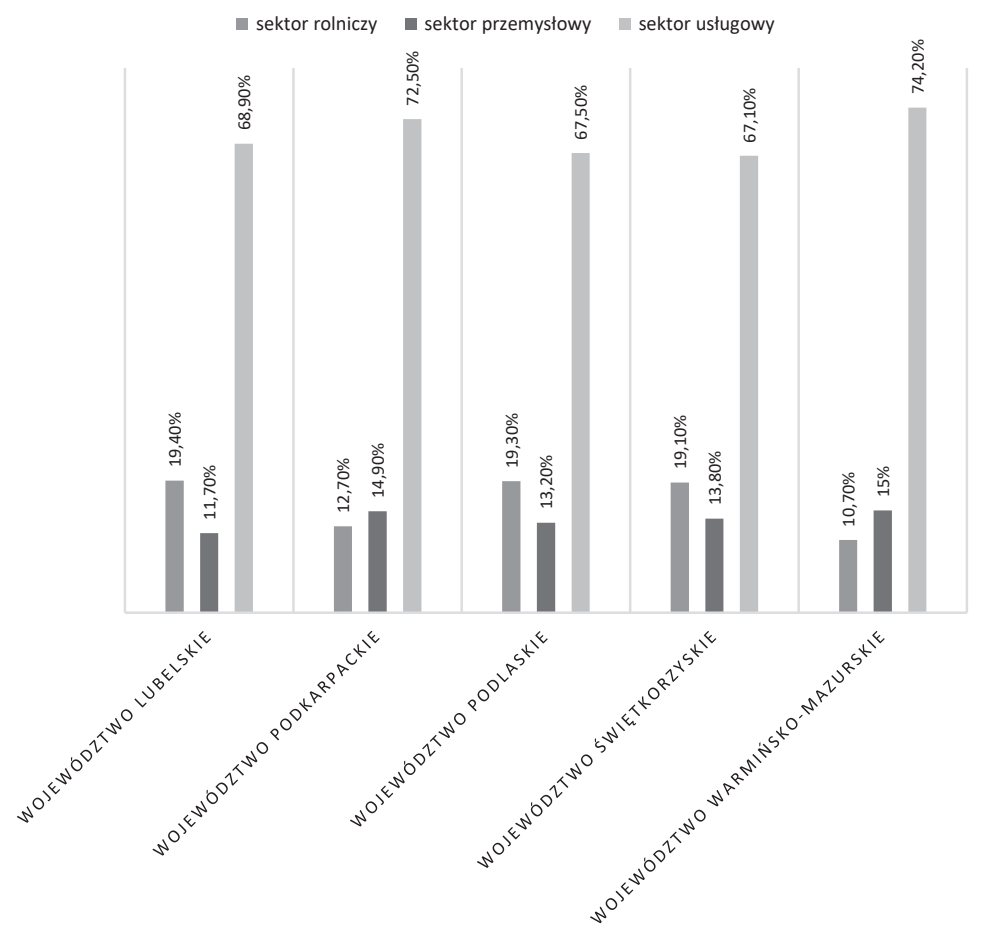

Źródło: opracowanie własne na podstawie danych z Urzędu Statystycznego $w$ Rzeszowie. 
Wykres 8. Pracujący mężczyźni wg sektorów ekonomicznych w pięciu województwach w 2016 r. (w \%)

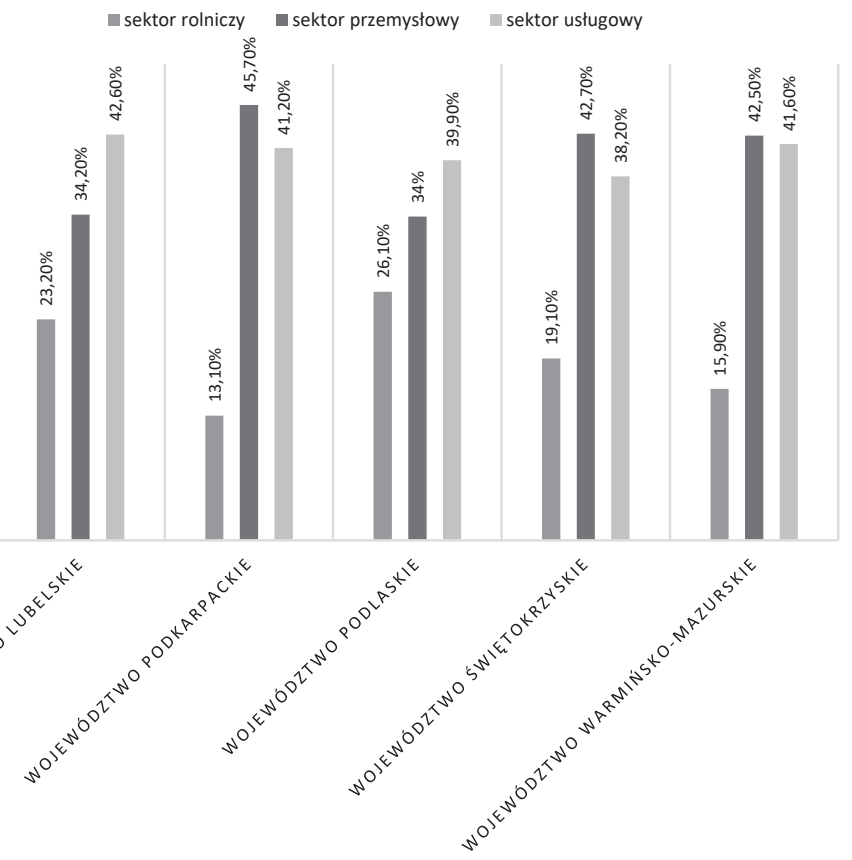

Źródło: opracowanie własne na podstawie danych z Urzędu Statystycznego $w$ Rzeszowie.

Spośród analizowanych województw trzy (podkarpackie, świętokrzyskie, warmińsko-mazurskie) charakteryzują się niekorzystna sektorową struktura zatrudnienia mężczyzn w stosunku wskaźników osiaganych w skali kraju. Jedynie w woj. lubelskim i podlaskim udział zatrudnionych mężczyzn w sektorze usług jest większy niż w przemyśle. W żadnym badanym województwie wskaźnik zatrudnienia mężczyzn w usługach nie osiagnął jednak poziomu ogólnokrajowego. Natomiast wskaźniki udziału kobiet w zatrudnieniu w usługach tylko w woj. podkarpackim i warmińsko-mazurskim osiagają wartości porównywalne do wartości w skali kraju i wyższe wartości rozpiętości tego wskaźnika w stosunku do wskaźnika udziału mężczyzn w zatrudnieniu w usługach (odpowiednio 31,2 i 32,6 pkt. proc.). W województwach tych struktura sektorowa zatrudnienia kobiet jest więc najkorzystniejsza, ponieważ odsetek kobiet zatrudnionych w przemyśle jest także wyższy niż w rolnic- 
twie. Różnice między wskaźnikami udziału zatrudnienia kobiet w przemyśle a wskaźnikami udziału zatrudnienia mężczyzn w przemyśle w woj. podkarpackim, świętokrzyskim i warmińsko-mazurskim przewyższaja różnicę w skali ogólnokrajowej (różnice te wynoszą odpowiednio - 30,8, 28,9 i 27,5 pkt. proc.). Różnice między wskaźnikami udziału zatrudnienia kobiet w rolnictwie a wskaźnikami udziału zatrudnienia mężczyzn $\mathrm{w}$ rolnictwie w woj. lubelskim, podlaskim i warmińsko-mazurskim przewyższają różnicę w skali ogólnokrajowej (wynoszą odpowiednio - 3,8, 6,8 i 5,2 pkt. proc.).

Udział zatrudnienia kobiet w decydujacym o nowoczesnym rozwoju kraju sektorze usług przewyższa udział mężczyzn.

\section{Fluktuacja siły roboczej}

Fluktuacja pracowników, czyli płynność kadr polegająca na przychodzeniu i odchodzeniu $z$ pracy $\mathrm{w}$ określonym czasie, jest procesem nieuniknionym i może przybierać cechy pozytywne, jak i negatywne, zarówno dla firmy, jak i dla pracownika. Przyczyny zwolnień z pracy moga mieć charakter niezależny lub zależny od pracownika. Wypadkową fluktuacji przy nadwyżce zwolnień w stosunku do przyjęć jest zjawisko bezrobocia. W artykule prześledzono wskaźniki zwolnień i przyjęć do pracy kobiet na tle zwolnień i przyjęć ogółem w skali ogólnopolskiej i w pięciu województwach wschodnich w badanym okresie.

Tabela 1. Zwolnienia $z$ pracy wg płci w Polsce i w pięciu województwach w 2015 r.

\begin{tabular}{|l|c|c|c|c|}
\hline Wyszczególnienie & $\begin{array}{c}\text { Zwolnienia } \\
\text { ogółem }\end{array}$ & $\begin{array}{c}\text { w tym } \\
\text { kobiety }\end{array}$ & $\begin{array}{c}\text { Współczynnik } \\
\text { zwolnień }\end{array}$ & $\begin{array}{c}\text { W tym } \\
\text { kobiety }\end{array}$ \\
\hline Polska & 1666439 & 691381 & 20,6 & 17,3 \\
\hline Woj. lubelskie & 50466 & 21401 & 16,0 & 13,1 \\
\hline Woj. podkarpackie & 60259 & 22259 & 17,4 & 13,5 \\
\hline Woj. podlaskie & 27839 & 11217 & 16,1 & 12,3 \\
\hline Woj. świętokrzyskie & 34002 & 12305 & 18,4 & 13,4 \\
\hline $\begin{array}{l}\text { Woj. warmińsko- } \\
\text {-mazurskie }\end{array}$ & 44446 & 18662 & 20,1 & 16,5 \\
\hline
\end{tabular}

Źródło: opracowanie i obliczenia własne na podst. Rocznik statystyczny województw, GUS, Warszawa 2016, s. 292. 
Tabela 2. Przyjęcia do pracy wg płci w Polsce i w pięciu województwach w $2015 \mathrm{r}$.

\begin{tabular}{|l|c|c|c|c|}
\hline Wyszczególnienie & $\begin{array}{c}\text { Przyjęcia } \\
\text { ogółem }\end{array}$ & $\begin{array}{c}\text { W tym } \\
\text { kobiety }\end{array}$ & $\begin{array}{c}\text { Współczynnik } \\
\text { przyjęć }\end{array}$ & $\begin{array}{c}\text { W tym } \\
\text { kobiety }\end{array}$ \\
\hline Polska & 1803981 & 791141 & 22,3 & 20,0 \\
\hline Woj. lubelskie & 53190 & 24759 & 16,9 & 15,3 \\
\hline Woj. podkarpackie & 65855 & 25737 & 19,1 & 15,8 \\
\hline Woj. podlaskie & 30345 & 12958 & 17,6 & 14,4 \\
\hline Woj. świętokrzyskie & 37109 & 15074 & 20,2 & 16,6 \\
\hline $\begin{array}{l}\text { Woj. warmińsko- } \\
\text {-mazurskie }\end{array}$ & 47692 & 21381 & 21,6 & 19,1 \\
\hline
\end{tabular}

Źródło: opracowanie i obliczenia własne na podst. Rocznik statystyczny województw, GUS, Warszawa 2016, s. 291.

Wskaźniki zwolnień i przyjęć kobiet w Polsce są niższe niż wskaźniki zwolnień i przyjęć ogółem - o 3,3 i 2,3 pkt. proc. - i wynoszą odpowiednio 17,3 i $20,0 \%$. We wszystkich badanych województwach osiagają one wartości niższe aniżeli w skali ogólnopolskiej. W woj. podlaskim wskaźnik zwolnień wynoszący $12,3 \%$, jako najniższy w stosunku do innych czterech badanych województw, jest o 3,8 pkt. proc. niższy od wskaźnika zwolnień ogółem w tym województwie. Wskaźnik przyjęć wynoszący $14,4 \%$, jako również najniższy do pozostałych badanych województw, jest o 3,2 pkt. proc. niższy od wskaźnika przyjęć ogółem w woj. podlaskim. W woj. warmińsko-mazurskim wartości tych wskaźników dla kobiet są najwyższe w porównaniu do innych badanych województw i wynoszą odpowiednio 16,5 i 19,1\%, co daje różnicę odpowiednio 3,6 pkt. proc. mniej niż wskaźnik zwolnień ogółem w tym województwie i 2,5 pkt. proc. mniej niż wskaźnik przyjęć ogółem.

Wyższe wskaźniki przyjęć niż zwolnień dla kobiet w skali krajowej i w badanych województwach należy oceniać jako zjawisko pozytywne z punktu widzenia zagrożenia bezrobociem. Na korzyść kobiet w Polsce działa również skala różnic między wskaźnikami ogółem zwolnień $(20,6 \%)$ i przyjęć $(22,3 \%)$ a tymi wskaźnikami dla kobiet - odpowiednio 17,3 i 20,0\%. Różnica wskaźnika zwolnień wynosząca 3,3 pkt. proc. jest większa aniżeli różnica wskaźnika przyjęć - 2,3 pkt. proc. Udział kobiet zwalnianych z pracy jest mniejszy niż udział mężczyzn o 3,3 pkt. proc., a udział kobiet przyjmowanych do pracy jest mniejszy od udziału mężczyzn o 2,3 pkt. proc. 


\section{Migracje zagraniczne}

Polska ma wielowiekową historię emigracji zagranicznej o charakterze politycznym i ekonomicznym, a w ostatnich latach nasila się też zjawisko imigracji do Polski. W okresie transformacji systemowej zjawisko bezrobocia oraz swoboda przepływu siły roboczej między krajami Unii Europejskiej wpłynęły na wzrost skali migracji. Skutki wyjazdów z kraju w poszukiwaniu pracy i lepszych zarobków można rozpatrywać $\mathrm{w}$ aspektach ekonomicznych, społecznych i psychologicznych w skali jednostkowej, lokalnej i krajowej. Przebywanie na emigracji zagranicznej kobiet rodzi szczególnie negatywne skutki w sferze rodzinnej. Poniższe dane statystyczne ilustruja relacje emigrantów $z$ punktu widzenia płci $\mathrm{w}$ badanych obszarach. Wielkości te nie odzwierciedlaja jednak pełnego stanu migracji, nie obejmuja bowiem nierejestrowanego w statystykach emigracji zarobkowej przemieszczania się przez granice państwowe.

Wykres 9. Migracje kobiet i mężczyzn w Polsce i w pięciu województwach w 2016 r.

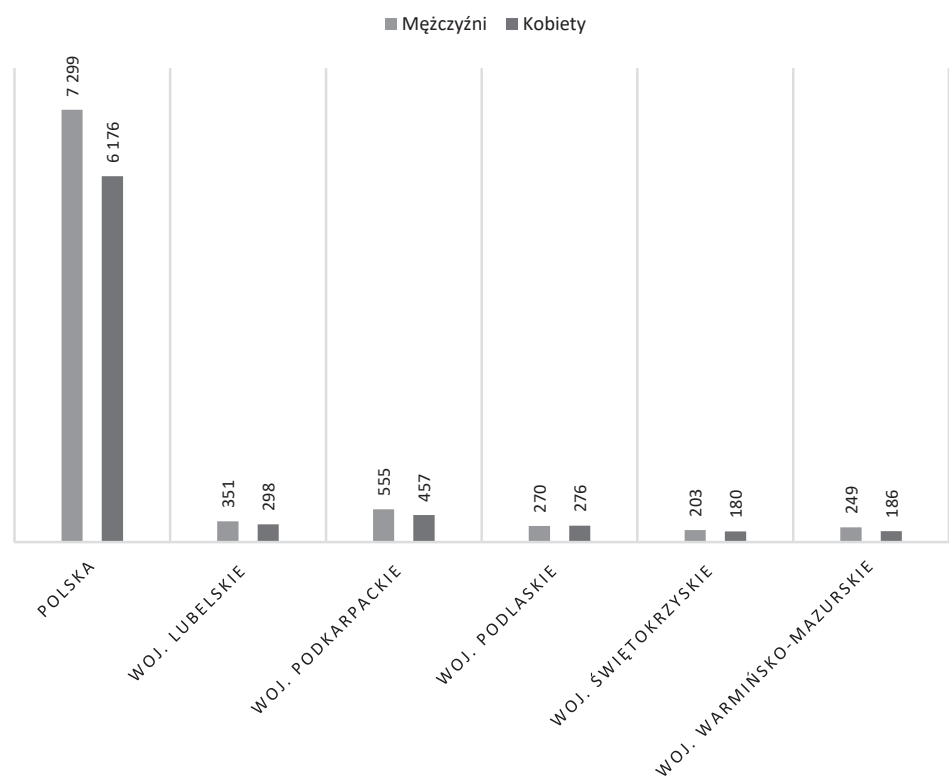

Źródto: opracowanie własne na podstawie danych z Urzędu Statystycznego $w$ Rzeszowie. 
Wskaźnik migracji zagranicznych dla mężczyzn jest wyższy niż dla kobiet o 1123 osoby. Tylko w woj. podlaskim wskaźnik migracji kobiet przewyższa wskaźnik migracji mężczyzn. Najmniejsze rozpiętości wskaźnika migracji między mężczyznami i kobietami są w woj. świętokrzyskim (23), a największe w podkarpackim (98). W woj. warmińsko-mazurskim różnica wynosi 63, a w lubelskim 53 osoby.

Mniejsze wartości migracji zagranicznych kobiet należy oceniać pozytywnie $z$ punktu widzenia ich społecznych skutków w wymiarze jednostkowym i lokalnym.

\section{Wynagrodzenia}

Tabela 3. Wynagrodzenia kobiet i mężczyzn w Polsce i w pięciu województwach w 2015 r.

\begin{tabular}{|l|c|c|c|c|c|c|c|c|c|}
\hline \multirow{2}{*}{$\begin{array}{c}\text { Wyszczególnie- } \\
\text { nie }\end{array}$} & \multicolumn{3}{|c|}{$\begin{array}{c}\text { Przeciętne } \\
\text { wynagrodzenie } \\
\text { miesięczne brutto }\end{array}$} & \multicolumn{3}{c|}{$\begin{array}{c}\text { Mediana } \\
\text { wynagrodzeń } \\
\text { miesięcznych } \\
\text { brutto }\end{array}$} & \multicolumn{3}{c|}{$\begin{array}{c}\text { Przeciętne } \\
\text { godzinowe } \\
\text { wynagrodzenie } \\
\text { brutto }\end{array}$} \\
\cline { 2 - 11 } & $\mathbf{M}$ & $\mathbf{K}$ & $\mathbf{K}: \mathbf{M} \%$ & $\mathbf{M}$ & $\mathbf{K}$ & $\mathbf{K}: \mathbf{M} \%$ & $\mathbf{M}$ & $\mathbf{K}$ & $\mathbf{K}: \mathbf{M} \%$ \\
\hline Polska & 4482 & 3718 & 83,0 & 3486 & 3100 & 88,9 & 24,32 & 21,35 & 89,8 \\
\hline Woj. lubelskie & 3666 & 3351 & 91,4 & 3100 & 2964 & 95,6 & 20,26 & 19,80 & 97,7 \\
\hline $\begin{array}{l}\text { Woj. } \\
\text { podkarpackie }\end{array}$ & 3622 & 3143 & 86,8 & 3008 & 2898 & 96,3 & 19,88 & 18,46 & 92,9 \\
\hline Woj. podlaskie & 3631 & 3466 & 95,5 & 3057 & 3036 & 99,3 & 19,84 & 20,53 & 103,5 \\
\hline $\begin{array}{l}\text { Woj. } \\
\text { swiętokrzyskie }\end{array}$ & 3813 & 3389 & 88,8 & 3134 & 2915 & 93,0 & 20,75 & 19,46 & 93,8 \\
\hline $\begin{array}{l}\text { Woj. warmińn- } \\
\text { sko-mazurskie }\end{array}$ & 3557 & 3317 & 93,3 & 3121 & 2911 & 93,3 & 19,36 & 19,10 & 98,7 \\
\hline
\end{tabular}

Źródło: opracowanie i obliczenia własne na podst. Różnice $w$ wynagrodzeniach kobiet i mężczyzn w Polsce, Urząd Statystyczny, Rzeszów 2016. 
Wykres 10. Przeciętne wynagrodzenie miesięczne brutto wg płci w Polsce i w pięciu województwach w 2015 r.

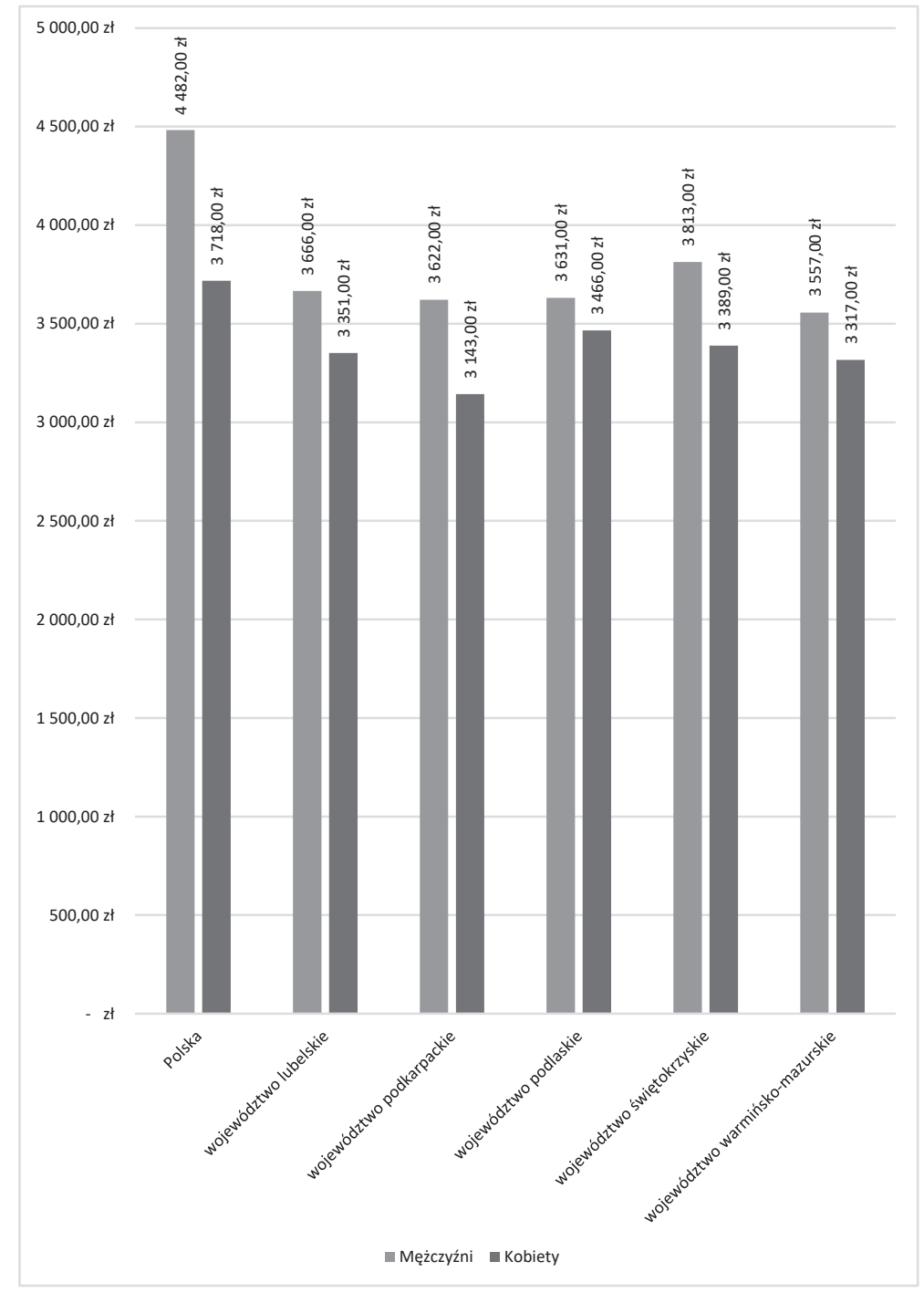

Źródło: opracowanie własne na podstawie danych z Urzędu Statystycznego $w$ Rzeszowie.

Przeciętne wynagrodzenie miesięczne brutto kobiet jest w Polsce niższe w stosunku do wynagrodzeń mężczyzn o 764 zł i wynosi 3718 zł. We wszystkich badanych województwach poziom wynagrodzeń brutto mężczyzn i kobiet jest niższy w stosunku do wysokości wynagrodzenia 
brutto w skali kraju. W woj. podlaskim wynagrodzenie miesięczne brutto kobiet jest niższe w stosunku do wynagrodzeń miesięcznych brutto mężczyzn tylko o 165 zł, w warmińsko-mazurskim o 240 zł, w lubelskim o 315 zl, w świętokrzyskim o 424 zl, a w podkarpackim o 479 zl. W woj. podkarpackim różnica ta jest największa, ale i nominalne wynagrodzenie kobiet jest tu najniższe w stosunku do wszystkich porównywanych jednostek terytorialnych i wynosi 3143 zł, czyli o 575 zł mniej niż w skali krajowej i o 323 zł mniej w stosunku do woj. podlaskiego, gdzie wynagrodzenie kobiet jest najwyższe spośród pięciu badanych województw Polski wschodniej.

Wykres 11. Stosunek płac kobiet do płac mężczyzn w 2015 r.

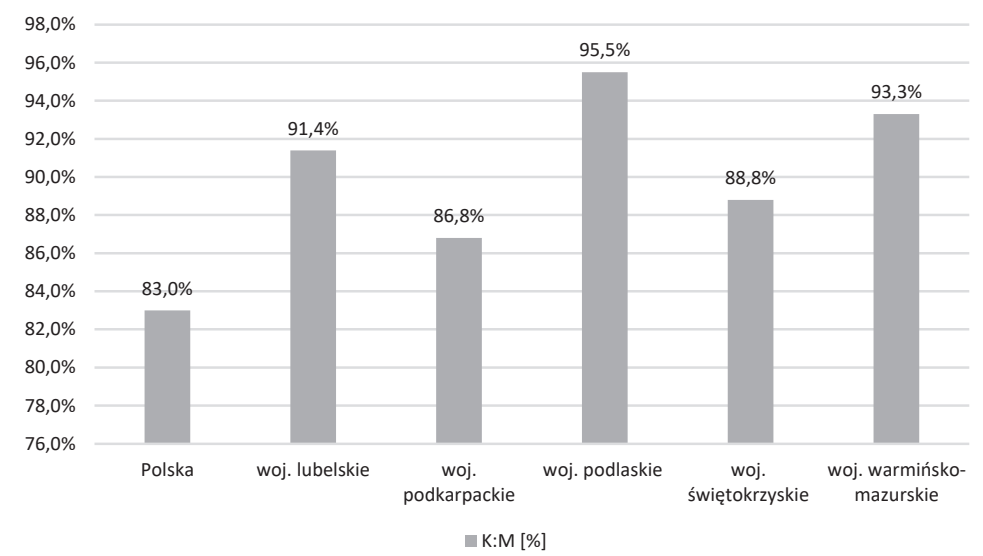

Źródło: opracowanie własne na podstawie danych z Urzędu Statystycznego $w$ Rzeszowie.

W skali kraju wynagrodzenie miesięczne brutto kobiet stanowi 83\% wynagrodzeń miesięcznych brutto mężczyzn, nieco wyższa jest mediana wynagrodzeń miesięcznych brutto na poziomie $98,9 \%$ i wynagrodzenie godzinowe brutto wynoszace $89,8 \%$. W badanych województwach rozpiętości płac kobiet i mężczyzn są mniejsze niż w skali ogólnokrajowej. Najmniejsze rozpiętości występuja w woj. podlaskim (4,5\%), gdzie wynagrodzenie miesięczne brutto kobiet stanowi 83\% wynagrodzeń miesięcznych brutto mężczyzn, a największe w woj. podkarpackim $(13,2 \%)$, gdzie wynagrodzenie miesięczne brutto kobiet stanowi $86,8 \%$ wynagrodzeń miesięcznych brutto mężczyzn. 
Po analizie wybranych wskaźników ilustrujących status kobiet w sferze zawodowej w pięciu województwach wschodniej Polski można wskazać, w których sytuacja kobiet jest najkorzystniejsza, a w których najmniej korzystna w porównaniu do innych badanych województw i do skali ogólnopolskiej oraz w stosunku do mężczyzn.

Najwięcej kobiet $z$ wykształceniem wyższym jest w woj. lubelskim. W woj. podlaskim wskaźniki aktywności zawodowej i zatrudnienia kobiet sa najbardziej zbliżone do średniej krajowej, a w woj. lubelskim są najbardziej zbliżone w stosunku do wskaźników aktywności zawodowej i zatrudnienia mężczyzn. Stopa bezrobocia kobiet jest najniższa w woj. podlaskim w stosunku do tego wskaźnika w skali kraju, a w woj. lubelskim jest najniższa w porównaniu ze stopa bezrobocia mężczyzn. Struktura sektorowa zatrudnienia kobiet w woj. podkarpackim i warmińsko-mazurskim świadczy o nowoczesności gospodarki w tych województwach. W woj. warmińsko-mazurskim wskaźnik przyjęć kobiet do pracy jest najwyższy, a w woj. podlaskim najniższy jest wskaźnik zwolnień kobiet $z$ pracy. Biorac pod uwage negatywne skutki społeczne emigracji zagranicznej kobiet dla rodzin pozostajacych w kraju, to w woj. podkarpackim wyjeżdża za granicę najmniej kobiet w porównaniu do liczby wyjeżdżających mężczyzn. W woj. podlaskim płace kobiet są najbardziej zbliżone do płac mężczyzn.

Najmniej kobiet $z$ wykształceniem wyższym jest w woj. warmińsko-mazurskim i tam wskaźniki aktywności zawodowej i zatrudnienia kobiet sa najniższe w porównaniu do średniej krajowej i do wskaźnika aktywności zawodowej i zatrudnienia mężczyzn. Stopa bezrobocia kobiet jest najwyższa w woj. podkarpackim w stosunku do tego wskaźnika w skali kraju, a w woj. warmińsko-mazurskim najwyższa do stopy bezrobocia mężczyzn. Struktura sektorowa zatrudnienia kobiet w woj. lubelskim, podlaskim i świętokrzyskim świadczy o niskim tempie unowocześniania gospodarki w tych województwach. W woj. warmińsko-mazurskim wskaźnik zwolnień kobiet z pracy jest najwyższy, a w woj. podlaskim najniższy jest wskaźnik przyjęć kobiet do pracy. Największa liczba kobiet w stosunku do liczby mężczyzn emigruje za granicę w woj. świętokrzyskim. W woj. podkarpackim płace kobiet sa najniższe w stosunku do płac mężczyzn. 


\section{Zakończenie}

Nowe role społeczne kobiet wywalczone na przełomie XIX i XX w. $z$ jednej strony dały im pozarodzinna pozycję $\mathrm{w}$ sferze zawodowej i publicznej, $z$ drugiej jednak doprowadziły do sprzeczności polegającej na ograniczeniu możliwości skutecznego wypełniania funkcji rodzinnych według dotychczasowych standardów, co może prowadzić do kryzysu w rodzinie. Kobiety wobec zrównania względem prawa i możliwości zdobywania wykształcenia uświadomiły sobie swoje położenie i zaczęły oczekiwać większej równości, partnerstwa w pracy zawodowej i w rodzinie. Ich oczekiwania zderzają się $z$ przeciwnymi tendencjami na rynku pracy. Nierówności między kobietami i mężczyznami mają dwa wymiary - obiektywność położenia (faktyczne nierówności) oraz delegitymizacja i uświadomienie. Amalgamat nowej świadomości i starego położenia jest wybuchowy. Coraz bardziej zaostrzają się sprzeczności między oczekiwaniami równości ze strony kobiet i rzeczywista nierównością oraz trzymaniem się mężczyzn dawnych ról ${ }^{4}$. Nasilające się działania feministek domagających się równouprawnienia we wszystkich sferach życia są widoczne nie tylko w obszarze rywalizacji z mężczyznami, lecz także moga przynosić dalekosiężne niepożądane następstwa społeczne objawiające się nasileniem chorób zawodowych kobiet pracujących w trudnych dla organizmu kobiecego warunkach, spadkiem dzietności kobiet czy opóźnianiem wieku rodzenia pierwszego dziecka. W konsekwencji może to prowadzić do: zmniejszenia przyrostu naturalnego, wzrostu skali rozwodów $z$ powodu konfliktów w małżeństwie ze względu na większe awanse zawodowe kobiet niż mężczyzn, wyższych zarobków kobiet, złego zachowania i patologii dzieci, którym robiące kariery matki nie poświęciły należnego czasu na opiekę i wychowanie. Pomimo że mężczyźni nadal są nadreprezentowani na szczycie piramidy społecznej, to na jej dole wykonuja najbrudniejsze i najniebezpieczniejsze zawody. Radykalne feministki, żądając parytetów, eksponuja strukturę procentowa niezadowalającego udziału kobiet na szczytach kariery zawodowej, politycznej i społecznej, ale nie doceniają faktu posiadania dominującego udziału kobiet w środkowym miejscu tej piramidy.

Przedstawiona $\mathrm{w}$ artykule wycinkowa analiza położenia kobiet i mężczyzn w sferze zawodowej na przykładzie województw Polski

4 U. Beck, op. cit., s. 152, 155, 166, 177. 
wschodniej miała na celu ukazanie zakresu nierówności z punktu widzenia różnicy płci. Porównywane parametry ekonomiczne rynku pracy z poszczególnych województw stanowiących ścianę wschodnia, uznawaną za mniej rozwiniętą gospodarczo od reszty Polski, ilustrowały zróżnicowanie pomiędzy tymi województwami oraz ich miejsce na tle ogólnopolskim. Zestawiając ze sobą analizowane wskaźniki odnoszące się do oceny położenia kobiet w stosunku do mężczyzn na rynku pracy, można sporządzić ranking tych województw $z$ najkorzystniejszymi i najmniej korzystnymi parametrami statusu kobiet w sferze zawodowej. $Z$ analizy wartości wskaźników wynika, że najczęściej przy pożądanych kierunkach kształtowania statusu kobiet na rynku pracy wymieniane jest woj. podlaskie, na drugim miejscu sytuuje się woj. lubelskie, woj. warmińsko-mazurskie natomiast zdecydowanie wyprzedza wszystkie pozostałe pod względem największej liczby kryteriów o niekorzystnych cechach dla zawodowego rozwoju kobiet.

$Z$ wyników analiz danych statystycznych nasuwa się konstatacja o dywersyfikacji nierówności między kobietami i mężczyznami w sferze zawodowej. Wyższy poziom wykształcenia kobiet niż mężczyzn nie przekłada się na wskaźniki aktywności zawodowej i zatrudnienia kobiet, które osiagają niższe wartości. Natomiast wysokość stopy bezrobocia kobiet $\mathrm{w}$ badanych województwach jest porównywalna do stopy bezrobocia mężczyzn. Zdecydowanie większy udział zatrudnienia kobiet w sferze usług oznacza, że praca kobiet przyczynia się do unowocześniania gospodarki w większym stopniu niż mężczyzn. Fluktuacja zatrudnienia kobiet jest niższa w porównaniu do przyjęć i zwolnień z pracy ogółem. Również niższy jest udział kobiet w migracjach zagranicznych. Rozpiętość w wysokości płac mężczyzn i kobiet jest w badanych województwach niższa $\mathrm{w}$ stosunku do rozpiętości w skali ogólnopolskiej. Powyższe wyniki badań nie wskazują jednoznacznie na silna dyskryminację kobiet w sferze zawodowej w badanych jednostkach terytorialnych. Gorsze parametry dotyczace kobiet w obszarze życia zawodowego nie zawsze sa zdeterminowane różnica płci, ale moga być powodowane innymi obiektywnymi i subiektywnymi czynnikami związanymi m.in. z większym obciążeniem kobiet w sferze rodzinnej.

Uwarunkowania wynikające $z$ postępu technicznego i zaszłości kulturowych nie pozwalaja na powrót do zmniejszenia obciażenia kobiet aktywnością zawodową i publiczną na rzecz zwiększenia aktywności w sferze rodzinnej. Nierealna jest także bezwzględna równość między 
kobietami i mężczyznami ze względów uwarunkowanych biologicznie, obyczajowo, społecznie i ekonomicznie. Dążenie do równego parytetu uczestnictwa kobiet i mężczyzn w życiu rodzinnym, zawodowym i publicznym może przynieść niepożądane i szkodliwe społecznie skutki wymienione wyżej. Będące w wieku rozrodczym kobiety, nadmiernie zaabsorbowane kariera zawodową czy działalnością w sferze publicznej moga bowiem odkładać decyzje prokreacyjne lub rezygnować $z$ macierzyństwa ze względu na trudności łączenia aktywności zawodowej z obowiązkami w sferze rodzinnej.

Dla zachowania równowagi w życiu indywidualnym i społecznym niezbędne są: zróżnicowane nasilenie ról społecznych w poszczególnych fazach życia kobiety, stworzenie ekonomicznych i społecznych warunków do wolności wyboru przez kobiety ról społecznych, kształtowanie opinii publicznej doceniającej kobietę w każdej z tych ról, stworzenie równości szans między kobietami i mężczyznami przy równych kompetencjach obu płci. Ideałem byłoby, aby kobieta miała możliwość wyboru zakresu realizacji ambicji zawodowych, działalności społecznej i spełniania się w sferze rodzinnej na poszczególnych etapach swojego życia. Aby wybór ten nie był ograniczany przez sytuację ekonomiczną i opinię społeczną, ale był zgodny $z$ misja, jaka kobiecie jest biologicznie przypisana, oraz potrzebami wynikajaccymi $z$ jej świata wartości.

\section{Bibliografia}

\section{Opracowania}

Bauman Zygmunt, Kubicki Roman, Zeidler-Janiszewska Anna, Życie w kontekstach. Rozmowy o tym, co za nami i o tym, co przed nami, Warszawa : Wydawnictwa Akademickie i Profesjonalne, 2009, ISBN 9788361408772. Beck Ulrich, Społeczeństwo ryzyka. W drodze do innej nowoczesności, przeł.

Stanisław Cieśla, Warszawa : Wydawnictwo Naukowe Scholar, 2002, ISBN 8388495992.

Castells Manuel, Siła tożsamości, przeł. Sebastian Szymański, Warszawa :

Wydawnictwo Naukowe PWN, 2008, ISBN 9788301155834.

Charewiczowa Łucja, Kobieta w dawnej Polsce. Do okresu rozbiorów, Poznań : PTPN, 2002, ISBN 837063334X. 
Głyda Barbara, Kanibalistyczne aspekty kultury immanencji czyli o zjadaniu innego, „Transformacje” 2008-2009, nr 3/4 i 1/4, s. 249-264, ISSN 1230-0292.

Marek-Zborowska Barbara, Kobiety sukcesu $i$ ich kariery $w$ województwie podkarpackim, Rzeszów : Wydawnictwo Uniwersytetu Rzeszowskiego, 2016, ISBN 9788379963492.

Misiaszek Maria, Kobiety z Wandalina, Warszawa : Ludowa Spółdzielnia Wydawnicza, 1978.

Ockrent Christine, Kobiety u władzy, przeł. Jolanta Kurska, Katarzyna Resztak, Warszawa : Prószyński i S-ka, 2007, ISBN 9788374696159.

Skrzypek Franciszek, Kobiety w spółdzielczości „Samopomoc Chłopska”, Warszawa : Wydawca Samopomoc Chłopska, 1987, ISBN 8320906520.

Turner Jonathan H., Socjologia. Koncepcje $i$ ich zastosowanie, przeł. Ewa Różalska, Poznań : Wydawnictwo Zysk i S-ka, 1998, ISBN 8371504594.

Wiśniewska Halina, Świat płci żeńskiej baroku zaklęty $w$ słowach, Lublin : Wydawnictwo UMCS, 2003, ISBN 832272036X.

Wosińska Wilhelmina, Psychologia życia społecznego. Podręcznik psychologii społecznej dla praktyków i studentów, Gdańsk : Gdańskie Wydawnictwo Psychologiczne, 2004, ISBN 83-89574-34-9. 